\title{
EFISIENSI DAN PRODUKTIVITAS PERBANKAN SEBELUM DAN SETELAH KRISIS KEUANGAN
}

\author{
EFFICIENCY AND PRODUCTIVITY OF BANKS BEFORE AND AFTER FINANCIAL CRISIS
}

\author{
Emil Fatmala*1, Dedi Budiman Hakim ${ }^{* *}$, dan Lukytawati Anggraeni**) \\ *) Bank Negara Indonesia (Persero). Tbk \\ Jl. Jenderal Sudirman Kav 1, Jakarta Pusat \\ $\left.{ }^{* *}\right)$ Departemen Ilmu Ekonomi, Fakultas Ekonomi dan Manajemen, Institut Pertanian Bogor \\ Jl. Agatis Kampus IPB Darmaga, Bogor 16680
}

\begin{abstract}
Global financial crisis has given negative effects for economic growth especially in banking industry. This research aimed to analyze the efficiency and productivity of banks before and after the financial crisis. To examine the bank efficiency, this research used Data Envelopment Analysis (DEA), and the Malmquist Index was used to determine the bank productivity. This research concluded that Indonesian banking is inefficient in its intermediation function. The results showed that the performance efficiency score before crisis was 0.806, and the after crisis score was 0.812. The banks that were efficient are shown in Bank Mandiri (Persero), Tbk; Bank Rakyat Indonesia (Persero), Tbk; and Bank Central Asia, Tbk which have the highest assets. Banks with high assets have extensive market forces and networks making them more efficient than banks with smaller asset. That indicates a strong impact of the total assets to the bank efficiency level. Citibank NA and Standard Chartered Bank, known as foreign banks, are also efficient. The bank productivities after crisis are increasing. The results showed that Malmquist's bank productivity was increasing during the research period, and the score was 1.002, indicating that technological change (frontier shift effect) index is the major source of productivity. Technological changes would support banks to be more efficient and productive.
\end{abstract}

Keywords: Banks, data envelopment analysis (DEA), malmquist index, Global financial, financial crisis

\begin{abstract}
Abstrak: Krisis keuangan global telah memberikan dampak buruk bagi perkembangan perekonomian dunia khususnya perbankan. Penelitian ini bertujuan untuk mengetahui efisiensi dan produktivitas sebelum dan setelah krisis keuangan serta mengetahui strategi yang dapat diterapkan. Metode analisis yang akan digunakan untuk mengetahui efisiensi bank, yaitu Data Envelopment Analyis (DEA) dan Indeks Malmquist akan digunakan untuk mengetahui produktivitas bank. Kondisi yang efisien ditunjukkan oleh angka satu. Hasil analisis diketahui bahwa fungsi intermediasi perbankan di Indonesia belum efisien. Nilai efisiensi rata-rata sebelum krisis adalah sebesar 0,806 dan mengalami peningkatan pada periode setelah krisis menjadi sebesar 0,812. Bank yang efisien, yaitu Bank Mandiri (Persero), Tbk; Bank Rakyat Indonesia (Persero), Tbk dan Bank Central Asia, Tbk merupakan bank dengan aset terbesar. Bank dengan aset besar memiliki kekuatan pasar dan jaringan yang luas sehingga lebih efisien dibandingkan dengan bank dengan aset yang lebih kecil. Hasil penelitian juga menujukkan bahwa Citibank NA dan Standard Chartered Bank yang termasuk dalam kelompok Kantor Cabang Bank Asing merupakan bank yang efisien. Produktivitas bank pada periode setelah krisis mengalami peningkatan. Hasil penelitian menunjukkan produktivitas malmquist mengalami peningkatan pada periode penelitian dengan nilai ratarata 1,002. Peningkatan produktivitas didominasi oleh perubahan teknologi (efek frontier shift). Perubahan teknologi akan mendorong perbankan agar lebih efisien dan produktif.
\end{abstract}

Kata kunci: bank, data envelopment analysis (DEA), indeks malmquist, keuangan global, krisis keuangan

${ }^{1}$ Corresponding author:

Email: emil.fatmala@gmail.com 


\section{PENDAHULUAN}

Perbankan memiliki peran penting dalam proses pembangunan dan pertumbuhan serta salah satu indikator utama stabilitas ekonomi negara. Pentingnya peranan bank dan besarnya tingkat kepercayaan masyarakat yang harus dijaga, menyebabkan perbankan menjadi industri yang sangat diatur oleh pemerintah. Manajemen bank perlu membangun kepercayaan masyarakat untuk menjalankan bisnis perbankan. Hal ini terkait dengan fungsi dari bank sebagai lembaga intermediasi antara pihak-pihak yang memiliki dana dengan pihak-pihak yang memerlukan dana serta lembaga yang memperlancar aliran lalu lintas pembayaran.

Menghadapi era pasar bebas dan globalisasi, bank dituntut memiliki kinerja yang baik agar semakin efisien dan tetap dapat bertahan. Kesehatan bank merupakan kepentingan semua pihak terkait, baik pemilik, manajemen bank, masyarakat pengguna jasa bank, Bank Indonesia serta Otoritas Jasa Keuangan selaku pengawasan perbankan dan pemerintah. Kinerja perbankan menurut Athanasoglou et al. (2006) dipengaruhi oleh faktor internal dan faktor eksternal. Salah satu faktor eksternal yang memengaruhi kinerja perbankan adalah lingkungan ekonomi seperti krisis ekonomi.

Kinerja perbankan nasional diketahui dari total Dana Pihak Ketiga (DPK) dan kredit yang disalurkan. Secara keseluruhan, dapat dilihat pada Gambar 1 bahwa total DPK dan kredit yang diberikan mengalami peningkatan setiap tahunnya. Kondisi tersebut berbeda dengan pertumbuhan total DPK dan kredit yang diberikan yang mengalami fluktuasi. Penurunan pertumbuhan total DPK dan kredit yang diberikan terjadi pada tahun 2009. Penurunan tersebut karena terjadi krisis keuangan

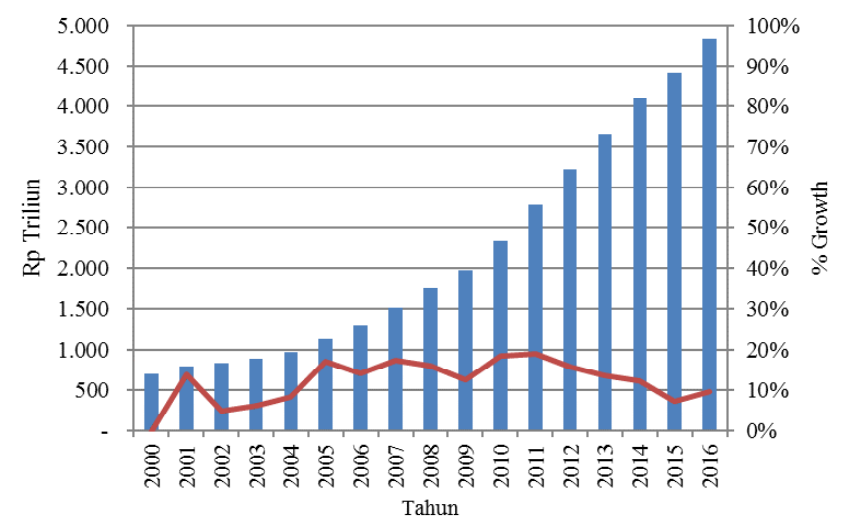

pada akhir tahun 2008. Hal ini sesuai dengan penelitian yang dilakukan oleh Sudarsono (2009) menyatakan bahwa krisis keuangan global memengaruhi kondisi perbankan Indonesia.

Konsep efisiensi menjelaskan hubungan teknis antara faktor input dan output yang menggambarkan proses transformasi input menjadi output pada satu periode tertentu. Konsep efisiensi juga sering dihubungkan dengan konsep produktivitas. Fried et al. (1993) mendefinisikan produktivitas dalam suatu unit produksi sebagai rasio dari output terhadap input produksinya.

Wilson (2006) menyatakan bahwa masalah efisiensi menjadi hal yang sangat penting karena kompetisi yang bertambah ketat, permasalahan yang timbul akibat berkurangnya sumber daya dan meningkatnya standar kepuasan nasabah. Efisiensi menjadi faktor yang mencerminkan penggunaan sumber daya (input) yang ada untuk memperoleh hasil (output) yang maksimum. Jika bank sebagai lembaga intermediasi menjadi lebih efisien dan produktif maka diharapkan laba akan meningkat serta security, ketepatan dan tingkat pengembalian yang lebih baik bagi nasabah maupun pemegang saham.

Indikator sebagai acuan penentuan efisiensi yang sering digunakan adalah rasio Beban Operasional Pendapatan Operasional (BOPO). Semakin besar Rasio BOPO maka semakin tidak efisien suatu bank. Rasio BOPO seperti yang terlihat pada Gambar 2 berfluktuatif. Jika ditarik garis linear trendline pada periode 2002-2008 bahwa garis tersebut bergerak dari $91 \%$ hingga menjadi $87 \%$. Jika ditarik garis linear trendline pada periode 2008-2016, garis tersebut bergerak dari 88\% hingga menjadi $77 \%$. Hal ini menunjukkan kondisi yang lebih baik dibandingkan periode sebelum terjadinya krisis keuangan tahun 2008.

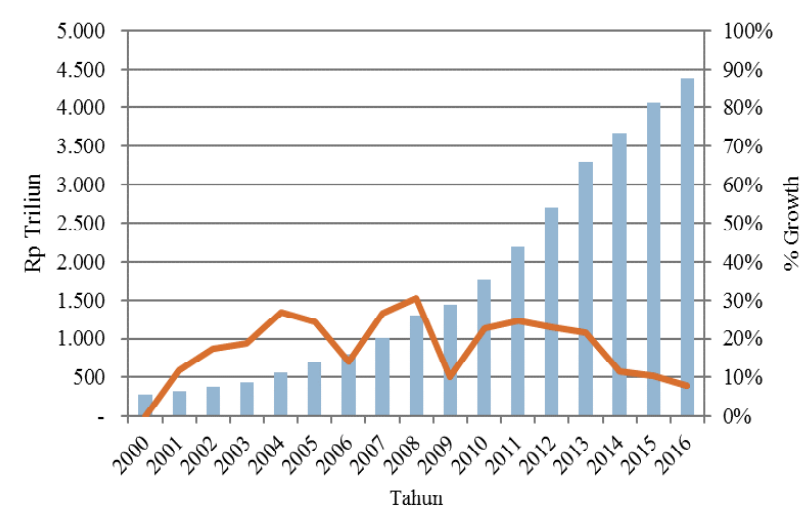

Gambar 1. Total DPK dan kredit yang disalurkan tahun 2000-2016 


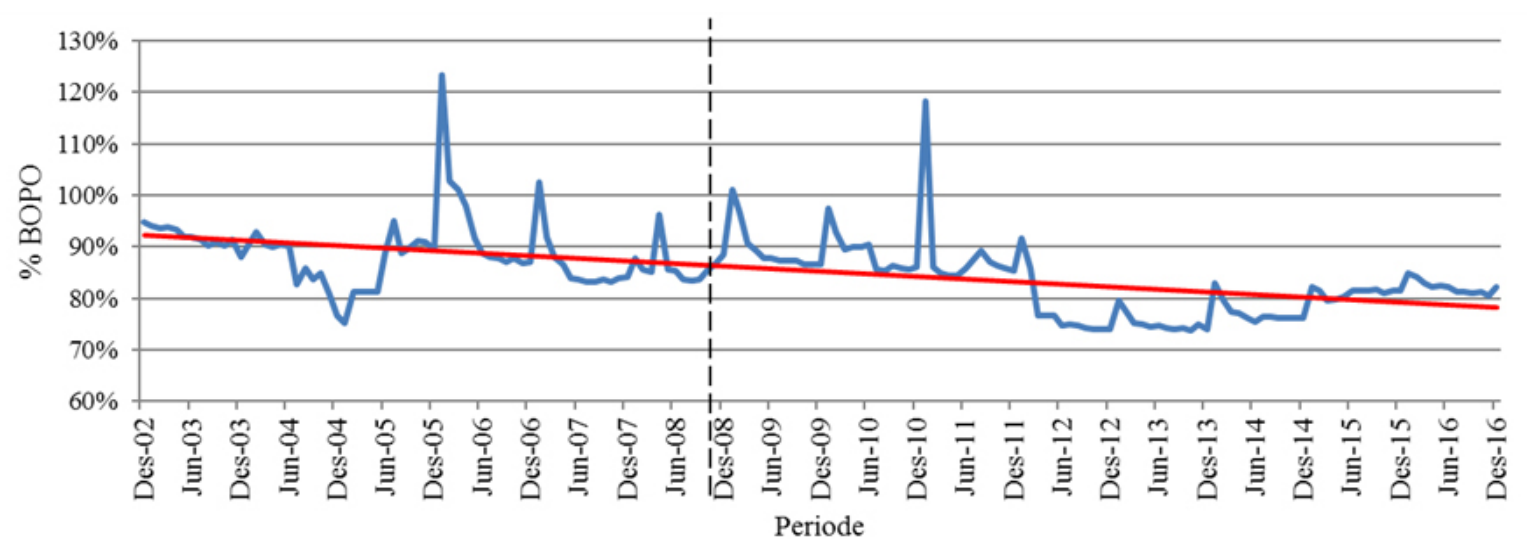

Gambar 2. Rasio beban operasional pendapatan operasional (BOPO) periode 2002-2016 (Garis pembatas sebelum dan setelah krisis (- - - )).

Sufian dan Habibullah (2011) di Thailand dan Mehta (2012) di Uni Eropa telah melakukan penelitian mengenai dampak krisis keuangan global terhadap perbankan. Hasilnya menunjukkan bahwa krisis keuangan global memberikan dampak buruk bagi perekonomian khususnya perbankan. Penelitian mengenai dampak krisis terhadap efisiensi perbakan di Indonesia juga telah di lakukan di Indonesia. Sutawijaya dan Lestari (2009) melakukan penelitian mengenai dampak krisis tahun 1998 pada 12 bank di Indonesia dengan hasil penelitian bahwa seluruh bank mengalami penurunan efisiensi selama krisis tahun 1998. Pratikno dan Sugianto (2011) memperoleh hasil penelitian bahwa tidak terdapat perbedaan yang signifikan mengenai efisiensi perbankan syariah sebelum dan setelah krisis keuangan tahun 2008. Penelitian tentang efisiensi dan produktivitas perbankan (konvensional) periode sebelum dan setelah krisis keuangan tahun 2008 belum dilakukan.

Tujuan penelitian ini adalah menganalisis efisiensi serta produktivitas perbankan periode sebelum dan setelah krisis keuangan. Hasilnya berguna bagi beberapa pihak khususnya perbankan untuk menetapkan strategi bisnis. Bagi regulator hasil penelitian diharapkan mampu memberikan informasi dan sebagai bahan pertimbangan untuk menyusun kebijakan.

Ruang lingkup penelitian ini adalah mengukur efisiensi dan produktivitas perbankan pada periode sebelum dan setelah krisis keuangan tahun 2008. Konsep efisiensi dan produktivitas menjelaskan hubungan teknis antara faktor input dan output. Efisiensi dan produktivitas dalam satu unit produksi merupaka rasio dari output terhadap input produksinya.

\section{METODE PENELITIAN}

Penelitian ini menggunakan data sekunder, yakni laporan keuangan publikasi bank tahunan yang terdapat dalam direktori Bank Indonesia (BI) dan Otoritas Jasa Keuangan (OJK). Data yang digunakan adalah data tahunan pada tahun 2001-2016. Penelitian menggunakan purposive sampling menggunakan bank konvensional di Indonesia. Jumlah sampel yang digunakan sebanyak 88 bank. Dalam penelitian ini semua bank umum konvensional yang beroperasi di Indonesia dan memiliki data/laporan keuangan sejak tahun 2001 sampai dengan tahun 2016 dijadikan sampel penelitian. Sampel penelitian terdiri dari empat Bank Persero, 19 Bank Umum Swasta Nasional Devisa, 22 Bank Umum Swasta Non Devisa, 26 Bank Pembangunan Daerah, sepuluh Bank Campuran dan tujuh Kantor Cabang Bank Asing. Analisis yang akan digunakan untuk tujuan pertama yaitu mengetahui efisiensi perbankan akan digunakan Data Envelopment Analysis (DEA) dan untuk mengetahui tujuan kedua, yaitu perubahan produktivitas alat analisis yang akan digunakan adalah Indeks Malmquist.

Analisis DEA berbasis evaluasi efisiensi relatif dari bank atau diistilahkan dengan Decision Making Unit (DMU) yang diperbandingkan yang menggunakan data eksisting (empiris) dari performance setiap unit yang membentuk pola efisiensi frontier (Cooper et al. 2000). Menurut Charnes et al. (1978), efisiensi relatif bank dalam DEA juga didefinisikan sebagai rasio dari total output tertimbang dibagi total input tertimbang (total weighted output/total weighted input), yang diformulasikan sebagai berikut: 


$$
E_{m}=\frac{\sum_{r=1}^{s} \mathrm{u}_{\mathrm{r}} \mathrm{y}_{\mathrm{ro}}}{\sum_{i=1}^{m} \mathrm{v}_{\mathrm{i}} \mathrm{x}_{\mathrm{io}}}
$$

Keterangan: Em (efisiensi dari bank ke-m); s (jumlah output); $\mathrm{U}_{\mathrm{r}}$ (bobot output ke-r); $\mathrm{y}_{\text {or }}$ (jumlah output ke-r yang diproduksi oleh bank b $_{0}$; m (jumlah input); $\mathrm{v}_{\mathrm{i}}$ (bobot input ke-i); $\mathrm{x}_{\mathrm{io}}$ (jumlah input ke-i yang digunakan oleh bank ${ }_{0}$ ).

Setiap bank atau DMU diasumsikan bebas menentukan bobot (weight) untuk setiap variabel-variabel input maupun output yang ada, dengan kondisi yang disyaratkan (Cooper et al. 2000), yakni bobot harus positif, rasio yang dihasilkan bernilai antara 0 dan 1 , dengan 1 adalah nilai efisiensi tertinggi dan bobot harus bersifat universal. Hal ini berarti setiap bank dalam sampel harus dapat menggunakan seperangkat bobot yang sama untuk mengevaluasi rasio tersebut tidak lebih dari 1 (total weighted output/total weighted input $\leq 1$ ). Nilai efisiensi dengan metode DEA berkisar 0 sampai dengan 1. Efisiensi bernilai 1 menunjukkan bank tersebut paling efisien dalam sampel pada periode tertentu, sedangkan nilai efisiensi bank lainnya relatif terhadap bank yang lebih efisien tersebut.

Penelitian ini menggunakan model variable return to scale (VRS) yang diperkenalkan oleh Banker et al. (1984). Model VRS mengasumsikan bahwa keadaan bank belum pada skala optimal. Pendekatan yang digunakan dalam penelitian ini adalah pendekatan intermediasi. Hal ini karena bank dinilai sebagai lembaga intermediasi antara pihak-pihak yang memiliki dana dengan pihak-pihak yang memerlukan dana. Analisis DEA membutuhkan variabel input dan output yang digunakan untuk mengukur efisiensi perbankan yang disajikan dalam Tabel 1.
Perbedaan efisiensi sebelum dan setelah terjadi krisis keuangan tahun 2008 maka dilakukan uji beda dengan pendekatan uji-t. Hipotesis penelitian ini adalah terdapat perbedaan efisiensi sebelum dan setelah terjadi krisis keuangan tahun 2008. Uji-t adalah jenis pengujian statistika untuk mengetahui apakah ada perbedaan dari nilai yang diperkirakan dengan nilai hasil penghitungan statistika. Uji ini umumnya digunakan untuk mengetahui perbedaan rata-rata antara dua populasi dengan mengambil sampel pada kedua populasi tersebut yang saling bebas atau independen (Kazmier dan Pohl, 1987).

Menurut Farel et al. (1989), Indeks Malmquist dapat diurai menjadi 2 komponen, yaitu komponen (efek catch-up) dan perubahan teknologi (efek frontier shift) sebagai berikut:

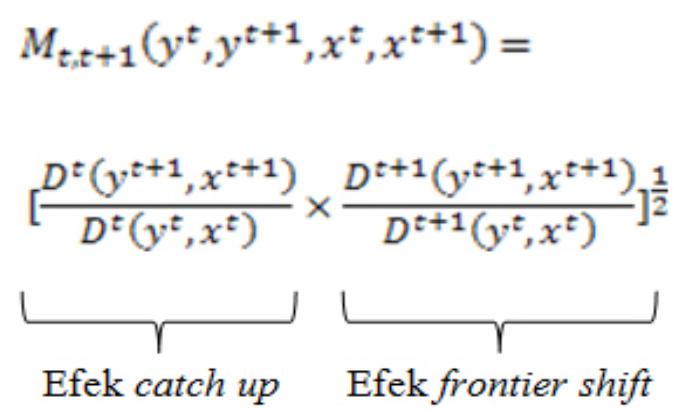

Notasi D mempresentasikan fungsi jarak dan nilai $\mathrm{M}$ merupakan indeks Malmquist, y merupakan output yang dihasilkan dan x merupakan input yang digunakan. Rasio efek catch-up mencerminkan perubahan efisiensi selama periode $\mathrm{t}$ dan $(\mathrm{t}+1)$ dengan menggunakan teknologi periode t sebagai benchmark. Di samping itu, efek frontier shift mencerminkan perubahan teknologi selama periode $\mathrm{t}$ dan $(\mathrm{t}+1)$ menggunakan teknologi periode $(\mathrm{t}+1)$ sebagai benchmark.

Tabel 1. Input dan output DEA

\begin{tabular}{llll}
\hline Keterangan & Jenis & Satuan & Sumber \\
\hline Input & Total dana pihak ketiga & Rupiah & Neraca \\
& Total beban bunga & Rupiah & Laba Rugi \\
& Total beban tenaga kerja & Rupiah & Laba Rugi \\
& Total aktiva tetap & Rupiah & Neraca \\
Output & Jumlah kredit yang diberikan & Rupiah & Neraca \\
& Total pendapatan bunga & Rupiah & Laba Rugi \\
& Total pendapatan non bunga & Rupiah & Laba Rugi \\
\hline
\end{tabular}


Pengukuran efisiensi dalam penelitian ini menggunakan pendekatan intermediasi karena kegiatan usaha lembaga jasa keuangan yang bertindak sebagai perantara (intermediasi). Penghitungan efisiensi perbankan dilakukan menggunakan DEA pada saat sebelum dan setelah terjadinya krisis keuangan. Dari hasil pengukuran tersebut dihasilkan skor efisiensi maing-masing bank. Perubahan produktivitas yang terjadi sebelum dan setelah terjadinya krisis keuangan menggunakan pengukuran indeks Malmquist. Hasil pegukuran efisiensi dan perubahan produktivitas diharapkan dapat menghasilkan implikasi manajerial bagi perbankan. Kerangka berpikir dapat dilihat pada Gambar 3.

Deskripsi data yang digunakan dapat dilihat pada Tabel 2. Selama tahun 16 tahun terakhir industri perbankan di Indonesia mengalami perkembangan yang cukup baik. Pertumbuhan terbesar yaitu pada pendapatan nonbunga sebesar 21,16\%, hal tersebut menunjukkan bahwa bank mulai berfokus pada pendapatan nonbunga. Pertumbuhan pendapatan nonbunga mampu tumbuh lebih besar dibandingkan pendapatan bunga, karena bank mulai fokus pada pendapatan nonbunga yang berasal dari fee based income misalnya pendapatan provisi, fee atau komisi atas pemasaran produk maupun transaksi jasa perbankan yang dibebankan kepada nasabah seperti letter of credit, garansi bank, transaksi trade, safe deposit box dan lain-lain.

Beban bunga dan pendapatan bunga memiliki pertumbuhan paling kecil masing-masing sebesar $7,88 \%$ dan $10,76 \%$. Hal ini karena suku bunga merupakan salah satu hal yang diatur oleh Bank Indonesia. Kredit yang disalurkan memiliki pertumbuhan sebesar 19,33\% lebih besar dibandingkan pertumbuhan DPK sebesar $12,63 \%$, hal tersebut menunjukkan bank mulai melakukan ekspansi untuk memperoleh pendapatan. Aktiva tetap mengalami peningkatan sebesar 19,33\% hal tersebut menunjukkan bahwa bank melakukan investasi pada aset tetap cukup besar untuk mendukung kegiatan operasional bank. Peningkatan tersebut juga disebabkan beberapa bank melakukan kebijakan revaluasi aset pada tahun 2016 untuk meningkatkan nilai buku aset tetap.

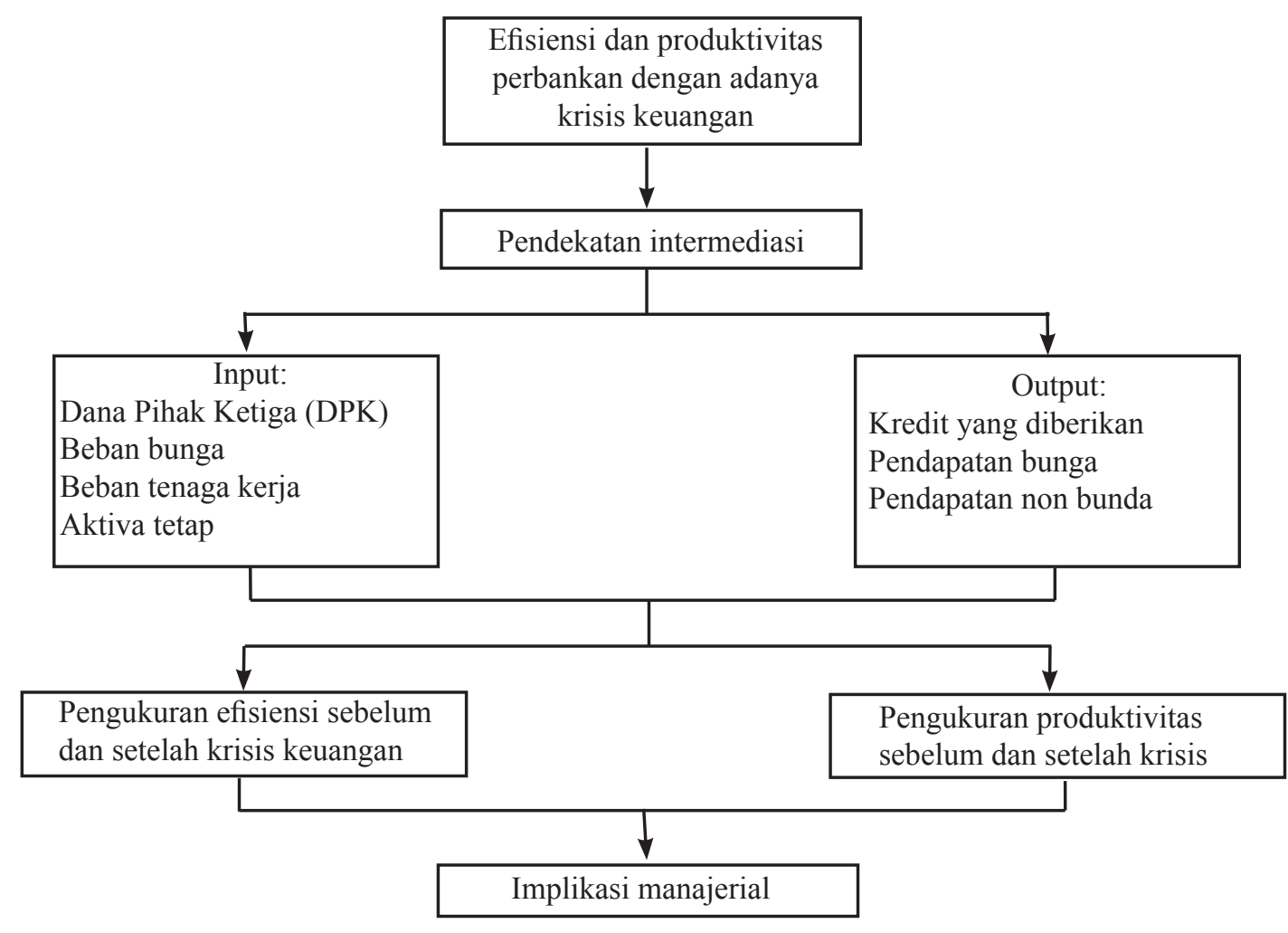

Gambar 3. Kerangka pemikiran 
Berdasarkan Tabel 2 juga diperoleh informasi perihal keragaman nilai variabel input dan output yang dicerminkan oleh nilai standar deviasi. Nilai keragaman terbesar adalah dana pihak ketiga dan kredit yang disalurkan. Hal ini mengindikasikan bahwa terdapat ketimpangan pencapaian dana pihak ketiga dan kredit yang disalurkan dari masing-masing bank. Kondisi ini dimungkinkan karena terdapat perbedaan skala jaringan dan pemasaran masing-masing bank, misalnya bank dengan aset besar memiliki kantor cabang pada seluruh Indonesia, dibandingkan dengan bank dengan aset kecil yang jaringan pemasarannya lebih sempit. Adapun nilai standar deviasi terendah adalah beban bunga yang menunjukkan bahwa beban bunga pada masing-masing bank mempunyai tingkat suku bunga yang relatif sama.

\section{HASIL}

\section{Pengukuran Efisiensi}

Hasil pengukuran efisiensi untuk 88 bank pada periode 2001-2016 diperoleh berkisar dari 0,111 sampai dengan 1.000 sebagaimana Tabel 3. Nilai efisiensi rata-rata sebelum krisis adalah sebesar 0,806 dan nilai efisiensi rata-rata setelah krisis adalah sebesar 0,812. Pada tahun 2009, yaitu periode setelah terjadi krisis tahun 2008, memiliki nilai efisiensi rata-rata terkecil dibandingkan dengan periode penelitan yaitu sebesar 0,743 . Setelah periode tersebut nilai efisiensi ratarata kembali membaik. Hasil ini menunjukkan bahwa perbankan Indonesia masih relatif jauh dengan frontier nya yang berarti masih relatif tidak efisien. Hasil ini sesuai dengan penelitian Fathony (2012), Sumarto (2014), Aviliani et al. (2015) dan Widiarti (2015) yang menyebutkan bank-bank umum di Indonesia secara keseluruhan belum beroperasi secara efisien periode sebelum dan setelah krisis keuangan.

Bank dengan skor efisiensi 1 pada sebelum dan setelah krisis sebanyak $6 \%$ atau sebanyak lima bank yaitu Bank Mandiri (Persero), Tbk; Bank Rakyat Indonesia (Persero), Tbk; Bank Central Asia, Tbk; Citibank NA; dan Standard Chartered Bank. Hal ini menunjukkan bahwa pada kelima bank tersebut, krisis keuangan tidak memengaruhi efisiensinya.

Bank Mandiri (Persero), Tbk; Bank Rakyat Indonesia (Persero), Tbk; dan Bank Central Asia, Tbk memiliki skor efisiensi 1 dan merupakan bank dengan aset terbesar. Bank dengan aset besar memberikan rasa aman bagi para nasabah sehingga meningkatkan DPK dan meningkatkan peluang untuk melakukan ekspansi kredit. Hauner (2005) menjelaskan bahwa bank yang besar memiliki kekuatan pasar dan mampu beroperasi lebih efisien melalui alokasi biaya tetap terhadap volume pelayanan yang lebih tinggi. Widiarti (2015) menyatakan bahwa bank dengan aset yang besar memiliki infrastruktur berupa sumber daya, teknologi informasi, jaringan kantor yang tersebar di seluruh indonesia untuk mendukung kegiatan operasional bank. Budiman et al. (2018) menyatakan bahwa bank dengan aset kecil menjadi kurang leluasa untuk ekspansi pembiayaan dan mengembangkan segmen layanan. Studi efisiensi di Indonesia menunjukkan hubungan positif antara ukuran bank dengan tingkat efisiensi antara lain dikemukakan oleh Fathony (2012) dan Widiarti (2015). Hasil yang sama juga dibuktikan oleh studi Delis dan Papanikolaou (2009) yang melakukan penelitian di Uni Eropa dan Alber (2015) yang melakukan penelitian di Mesir bahwa ukuran bank berpengaruh positif terhadap efisiensi.

Citibank NA dan Standard Chartered Bank termasuk Kantor Cabang Bank Asing. Kedua bank tersebut memiliki skor efisiensi 1 (satu), hal ini sesuai dengan penelitian Fathony (2012) bahwa bank asing lebih efisien. Kantor Cabang Bank Asing dapat lebih efisien karena memiliki sumber dana dari DPK berupa tabungan dan giro, tidak didominasi oleh deposito sehingga cost of fund relatif rendah karena suku bunga giro dan tabungan lebih rendah dibandingkan deposito. Hal ini sangat mendukung tingkat efisiensi Kantor Cabang Bank Asing. Wulansari dan Hermana (2008) menyatakan bahwa semakin tinggi cost of fund akibat struktur pendanaan yang mahal menyebabkan perbedaan antara biaya bunga dan pendapatan bunga semakin terbatas sehingga menurunkan kinerja keuangan bank. Sutardjo (2011) menurut hasil penelitannya menyebutkan bahwa kelompok bank asing memiliki nilai efisiensi di atas rata-rata industri karena bank asing mengandalkan pendapatan berupa fee dari jasa-jasa bank dibandingkan bank lainnya yang masih mengandalkan pendapatan berbasis bunga (interest based income). Menurut Berger dan Young (2001) bahwa bank asing yang beroperasi di negara berkembang dapat beroperasi secara efisien karena jaringan dan manajemen pengelolaannya yang berskala internasional. 
Hasil uji $\mathrm{t}$ keseluruhan menunjukkan bahwa nilai sig (2-tailed $)<0,05$ maka sesuai dasar pengambilan keputusan dapat disimpulkan H0 diterima. Artinya, tidak terdapat perbedaan antara nilai efisiensi teknis rata-rata sebelum dan setelah krisis. Hasil uji beda yang menunjukkan tidak adanya perbedaan nyata antara periode sebelum dan setelah periode krisis menunjukkan bahwa krisis keuangan yang terjadi tidak berdampak terhadap tingkat efisiensi perbankan. Hal ini sesuai dengan penelitian yang dilakukan oleh Pratikno dan Sugianto (2011) bahwa tidak terdapat perbedaan kinerja efisiensi perbankan syariah di Indonesia sebelum dan setelah krisis.

Dilakukan uji t pada setiap bank hasilnya diperoleh sebanyak 15 bank atau sebesar $17 \%$ dari total perbankan yang memiliki nilai sig (2-tailed $)<0,05$ yang sesuai dasar pengambilan keputusan dapat disimpulkan $\mathrm{H} 0$ ditolak. Artinya, pada 15 bank tersebut terdapat perbedaan yang signifikan antara nilai efisiensi sebelum dan setelah krisis. Sebanyak enam bank mengalami perbaikan nilai yang signifikan pada periode setelah krisis. Keenam bank tersebut, yaitu Bank Oke Indonesia, Bank Sinarmas, Tbk, BPD Kalimantan Timur, BPD Kalimantan Tengah, BPD Nusa Tenggara Timur dan BPD Sumatera Utara. Hal ini menunjukkan bahwa periode setelah krisis keenam bank tersebut melakukan perbaikan sehingga nilai efisiensinya membaik secara signifikan. Sebanyak sembilan bank mengalami perburukan nilai yang signifikan pada periode setelah krisis. Kesembilan bank tersebut yaitu Bank Negara Indonesia (persero), Tbk, Bank Agris, Bank Antar Daerah, Bank ANZ Indonesia, Bank Bukopin, Tbk, Bank Capital Indonesia, Tbk, Bank Mega, Tbk, Bank Mestika Dharma, Tbk dan Bank National Nobu, Tbk. Hal ini menunjukkan pada kesembilan bank tersebut, krisis keuangan memiliki pengaruh yang signifikan terhadap nilai efisiensinya.

Nilai efisiensi rata-rata setelah krisis tahun 2008 mengalami peningkatan dibandingkan dengan nilai efisiensi rata-rata sebelum krisis tahun 2008. Terjadinya peningkatan rata-rata kinerja efisiensi ini menunjukkan bahwa beberapa bank mengalami peningkatan kinerja efisiensi pada periode sebelum krisis dengan periode setelah krisis. Sementara itu, pengujian hipotesis dengan menggunakan metode paired sample $\mathrm{t}$ test menyimpulkan bahwa tidak terdapat perbedaan yang signifikan pada kinerja efisiensi perbankan sebelum dan setelah krisis global. Hal ini menunjukkan bahwa krisis global tidak mengakibatkan perubahan yang cukup berarti pada kinerja efisiensi perbankan.
Tidak adanya perbedaan yang signifikan kinerja efisiensi perbankan periode sebelum dan setelah krisis mengindikasikan bahwa kegiatan operasional perbankan semakin optimal. Kebijakan yang dikeluarkan oleh Bank Indonesia berkaitan dengan tindakan antisipatif terhadap krisis global berjalan sesuai perencanaan. Krisis keuangan tahun 1998 telah memberikan pengalaman kepada Bank Indonesia untuk memitigasi ketika terjadi krisis global. Perbaikan yang dilakukan, antara lain transparansi yang memenuhi akuntabilitas dan efektifitas, profesionalisme, dan kompetensi, pemenuhan ketentuan perbankan dan prinsip kehatihatian. Menurut Darsana (2009) bahwa kebijakan fungsi pengawasan Bank Indonesia selama krisis global diarahkan kepada penguatan sistem melalui penerapan pengawasan berdasarkan risiko, evaluasi Good Corporate Governance (GCG), penilaian atas penerapan prinsip mengenal konsumen Know Your Customer (KYC) dan Undang-Undang Tidak Pidana Pencucian Uang (TPPU), serta peningkatan kompetensi pengawas dan pengembangan sistem informasi pendukung.

\section{Perubahan Produktivitas Bank}

Perubahan produktivitas yang diukur mencakup perubahan efisiensi teknis (efek catch up) dan perubahan teknologi (efek frontier shift). Efek catch up bersumber dari perubahan efisiensi kinerja suatu DMU selama dua periode waktu, contohnya adalah dengan jumlah pegawai yang sama, suatu bank dapat berhasil melakukan ekspansi pembiayaan yang lebih tinggi dibandingkan periode waktu sebelumnya. Efek frontier shift merupakan efek dari adanya inovasi teknologi atau penyerapan teknologi yang ada. Contoh teknologi yang dimaksud adalah inovasi-inovasi dalam melakukan pemasaran dengan memanfaatkan teknologi perbankan seperti internet banking, transactional banking services, dan Cash Management System.

Secara rata-rata nilai Indeks Malmquist dari perbankan periode sebelum dan setelah krisis bernilai 1,002. Nilai tersebut menunjukkan peningkatan produktivitas perbankan. Pertumbuhan produktivitas rata-rata tersebut disumbangkan oleh efek catch up rata-rata sebesar 0,947 dan efek frontier shift sebesar 1,029. Perubahan produktivitas yang diukur tersebut mencakup perubahan efisiensi teknis (efek catch up) dan perubahan teknologi (efek frontier shift). Efek catch up bersumber dari efisiensi kinerja suatu bank selama dua periode waktu dan efek frontier shift merupakan efek adanya inovasi atau penyerapan teknologi yang ada. 
Pada Gambar 4 kelompok 1 terdapat 13\% dari 88 bank yang mengalami efek catch up dan efek frontier shift, kelompok 2 sebanyak 69\% bank mengalami efek frontier shift tanpa efek catch up, kelompok 3 sebanyak 3\% bank mengalami efek catch up tanpa perbaikan teknologi, dan sisanya kelompok 4 sebesar $15 \%$ bank tidak mengalami efek catch up maupun efek frontier shift. Pertumbuhan produktivitas hanya berasal dari salah satu indikatornya, efek catch up atau efek frontier shift, hanya sebesar 13\% bank (kelompok 1) yang mengalami perbaikan keduanya.

Secara umum, peningkatan produktivitas dari bank yang diteliti didominasi oleh adanya perubahan teknologi. Dari total 88 bank, sebanyak 44 bank atau sebesar 50\% memiliki peningkatan produktivitas. Hasil penelitian pada Gambar 4 diketahui bahwa sebagian besar bank mengalami efek frontier shift merupakan efek adanya inovasi teknologi atau penyerapan teknologi yang ada. Hasil penelitian ini sesuai dengan penelitian yang dilakukan oleh Hon et al. (2011) dan Hayat (2017) bahwa perubahan produktivitas bank karena efek frontier shift. Huang dan $\mathrm{Hu}$ (2007) menyatakan bahwa teknologi merupakan faktor kritikal didalam memenangkan persaingan ekonomi global pada era digital karena dianggap dapat memenuhi keunggulan bersaing perusahaan. Kemajuan teknologi perbankan yang sangat pesat telah memungkinkan berkembangnya berbagai saluran distribusi elektronis untuk memasarkan produk dan jasa bank menjadi semakin beragam, mudah serta tidak terbatas (Budidarmo, 2010).

\section{Implikasi Manajerial}

Hasil penelitian menunjukkan bahwa bank yang efisien diantaranya merupakan bank dengan aset besar dan bank asing. Bank dengan aset yang besar memiliki kekuatan pasar dan mampu beroperasi lebih efisien melalui alokasi biaya tetap terhadap volume pelayanan yang lebih tinggi. Bank asing mampu bekerja dengan efisien karena memiliki struktur cost of fund yang rendah dan jaringan serta manajemen pengelolaan yang berskala internasional.

Bank umum konvensional pada periode penelitian dinilai belum efisien. Peningkatan efisiensi dapat dilakukan dengan cara memperbesar pendapatan atau memperkecil biaya. Perbankan perlu memperhatikan rasio penyaluran kredit terhadap dana pihak ketiga (financing to deposit ratio). Bank perlu melakukan ekspansi kredit agar tidak terdapat dana DPK yang mengendap. Potensi perbaikan lainnya yaitu memanfaatkan aktiva tetap yang dimiliki dengan optimal untuk pemasaran dana maupun kredit dengan konsep one stop shopping. Pemasaran perlu dilakukan secara horizontal dengan memperluas pasar dan cross sell dengan unit kerja/produk lain dan secara vertikal dengan meningkatkan penetrasi pasar yang sudah dikuasai. Bank harus mampu mengelola cost of fund sumber pendanaan untuk meningkatkan margin.

Hasil indeks malmquist diketahui bahwa perubahan produktivitas bank berasal dari perubahan teknologi. Perbankan perlu melakukan inovasi dan penelitian yang dapat meningkatkan produktivitas dan efisiensi seperti inovasi teknologi. Perubahan teknologi (efek frontier shift) dalam hal ini adalah bank melakukan inovasi dan penelitian dalam teknologi perbankan dengan metode baru seperti digital banking. Salah satu strategi yang dapat dilakukan dengan konsep digital banking, yaitu branchless banking untuk menangkap segmen pasar yang belum tergarap atau memperluas pasar yang sudah ada. Konsep tersebut akan mampu menurunkan beban operasional seperti sewa kantor dan listrik serta beban tenaga kerja. Nasabah akan mendapatkan kemudahan dalam akses layanan perbankan dan perbankan mampu meningkatkan efisiensinya.

Perubahan teknologi tersebut juga akan meningkatkan pendapatan nonbunga (fee based income) dari retail maupun corporate banking. Pendapatan nonbunga dari retail misalnya pendapatan atas biaya pembayaran rekening listrik, air, telepon, pengisian pulsa, pembayaran kartu kredit dan asuransi. Pendapatan nonbunga dari corporate banking misalnya garansi bank, L/C, payroll, transaksi forex, dan remittance.

Bagi BI dan OJK temuan ini memiliki implikasi penting sebagai panduan arah kebijakan perbankan ke depan dengan sasaran utamanya adalah untuk meningkatkan ketahanan perbankan. Regulator perlu merumuskan instrumen yang berbasis intermediasi sepertimendorong perbankan menyalurkan pembiayaan melalui rasio penyaluran kredit terhadap dana pihak ketiga (financing to depositratio). Kebijakan OJK melakukan pembatasan suku bunga deposito berdasarkan total aset dinilai tepat untuk mendukung pencapaian profitabilitas dan efisiensi perbankan. OJK perlu mendorong perbankan untuk melakukan digitalisasi agar beroperasi lebih efisien. 


\section{KESIMPULAN DAN SARAN}

\section{Kesimpulan}

Efisiensi perbankan Indonesia baik pada periode sebelum krisis dan setelah krisis masih relatif tidak efisien. Bank yang efisien, yaitu Bank Mandiri (Persero), Tbk; Bank Rakyat Indonesia (Persero), Tbk dan Bank Central Asia, Tbk merupakan bank dengan aset terbesar. Hasil penelitian juga menujukkan bahwa Citibank NA dan Standard Chartered Bank yang termasuk dalam kelompok Kantor Cabang Bank Asing merupakan bank yang efisien. Produktivitas bank pada periode setelah krisis mengalami peningkatan. Peningkatan produktivitas didominasi oleh perubahan teknologi (efek frontier shift).

\section{Saran}

Penelitian ini dapat dikembangkan dari aspek metode pengukuran efisiensi dan determinannya mengingat adanya keterbatasan dalam penelitian ini. Penambahan variabel dan periode data sangat dianjurkan agar diperoleh informasi yang lebih komprehensif. Selain itu, penggunaan metode analisis data yang berbeda juga akan memperkaya pemahaman mengenai efisiensi dan produktivitas.

\section{DAFTAR PUSTAKA}

Alber N. 2015. Determinants of banking efficiency: evidence from Egypt. International Business Research 8(8): 50-58. https://doi.org/10.5539/ ibr.v8n8p50.

Athanasoglou PP, Delis MD, Staikouras CK. 2006. Determinants of bank profitability in the South Eastern European Region. Economic Research Department Bank of Greece 47: 1-36.

Aviliani, Siregar H, Maulana TNA, Hasanah H. 2015. The impact of macroeconomic condition on the bank's performance in Indonesia. Buletin Ekonomi Moneter dan Perbankan 7(4): 379402. https://doi.org/10.21098/bemp.v17i4.503.

Berger A, Young R. 2001. The effects of geographic expansion on bank efficiency. Journal of Financial Services Research 19(2/3): 163-207.

Budidarmo RR. 2010. Rancang bangun sistem intelijen bisnis dalam pengambilan keputusan teknologi informasi perbankan [disertasi]. Bogor: Institut
Pertanian Bogor.

Budiman R, Achsani NA, Ismal R. 2018. Risiko pembiayaan dan determinannya pada perbankan syariah di Indonesia. Jurnal Aplikasi Bisnis Manajemen 4(1):151-159. https://doi. org/10.17358/jabm.4.1.151.

Charnes A, Cooper WW, Rhodes EL. 1978. Measuring the efficiency of decision making units. European Journal of Operational Research 2: 429-444. https://doi.org/10.1016/0377-2217(78)90138-8.

Cooper WW, Seiford LM, Tone K. 2000. Data Envelopment Analysis: A Comprehensive Text With Models, Application, References And DEA Solver Software. Dordrecht: Kluwer Academic Publisher.

Darsana IB. 2009. Kebijakan perbankan dalam mengatasi krisis keuangan global di Indonesia. Sarathi 16(3): 338-346.

Delis M, Papanikolaou NI. 2009. Determinants of bank efficiency evidence from a semiparametric methodology. Managerial Finance 35(3):260-275. https://doi. org/10.1108/03074350910931771.

Fathony M. 2012. Estimasi dan faktor-faktor yang memengaruhi efisiensi bank domestik dan asing di Indonesia. Jurnal Keuangan dan Perbankan 16(2): 223-237.

Hayat DS. 2017. Analisis efisiensi Bank EFG Syariah: pendekatan produktivitas dan profitabilitas [tesis]. Bogor: Institut Pertanian Bogor.

Hon LY, Tuck CE, Yu KL. 2011. Efficiency in the Malaysian banking industry. Asean Economic Bulletin 28(1): 16-44. https://doi.org/10.1355/ ae28-1b.

Huang CD, Hu Q. 2007. Achieving IT-business strategic alignment via enterprise wide implementation of balanced scorecard. Information Systems Managment 24: 173-184. https://doi. org/10.1080/10580530701239314.

Kazmier LJ, Pohl NF. 1987. Basic Statistic for Business and Economics. Singapore: McGraw Hill.

Mehta A, 2012. Financial performance of UAE banking sector - a comparison of before and during crisis ratios. International Journal of Trade, Economics and Finance 3(5): 381-387. https:// doi.org/10.7763/IJTEF.2012.V3.232.

Pratikno H, Sugianto I. 2011. Kinerja efisiensi bank syariah sebelum dan sesudah krisis global berdasarkan data envelopment analysis. Jurnal Ekonomi Bisnis 2: 108-117. 
Sudarsono, H. 2009. Dampak krisis keuangan global terhadap perbankan di Indonesia: perbandingan antara bank konvesional dan bank syariah. La Riba - Jurnal Ekonomi Islam 3(1): 12-23. https://doi.org/10.20885/lariba.vol3.iss1.art2.

Sufian F, Habibullah MS. 2010. Developments in the efficiency of the Thailand banking sector: a DEA approach. International Journal of Development 9(3): 226-245. https://doi. org/10.1108/14468951011073316.

Sumarto AH. 2014. Analisis frontier efficiency industri perbankan Indonesia dengan menggunakan metode parametrik: Distribution Free Approach [tesis]. Bogor: Institut Pertanian Bogor.
Sutawijaya A, Lestari EP. 2009. Efisiensi teknik perbankan Indonesia pasca krisis: sebuah studi empiris penerapan model DEA. Jurnal Ekonomi Pembangunan 10(1): 49-67. https://doi. org/10.23917/jep.v10i1.808.

Widiarti AW. 2015. Faktor-faktor yang memengaruhi efisiensi perbankan di Indonesia [tesis]. Bogor: Institut Pertanian Bogor.

Wilson A. 2006. Manajemen Perbankan Indonesia. Jakarta: LP3ES.

Wulansari N, Hermana B. 2008. Analisis biaya dana, persentase aktiva produktif, dan pendapatan sebagai faktor pembeda antara bank fokus dan bank terbatas menurut kerangka aristektur perbankan Indonesia. UG Jurnal 2(2): 1-14. 